\title{
RECENT INNOVATIONS TO PRETRIAL DISCOVERY SANCTIONS: RULE 37 REINTERPRETED
}

Working to eliminate the procedural maze which had developed in the federal courts, the framers of the Federal Rules of Civil Procedure produced what has been described as the "simplest and least technical procedure yet devised in Anglo-American jurisprudence." The basic philosophy of the Rules is unmistakable. ${ }^{2}$ The draftsmen sought to relieve federal procedure of both the rigidity of the pre-r 938 Codes and the last vestiges of common law pleading which constituted federal procedure under the late Conformity Act. ${ }^{3}$ An additional goal of the draftsmen was to soften, as far as practicable, the rigors of the AngloAmerican adversary system. The result was a mechanism highly conducive to the determination of cases on their merits rather than on procedural niceties. ${ }^{4}$

\footnotetext{
${ }^{1}$ Holtzoff, Origins and Sources of the Federal Rules of Civil Procedure, 30 N.Y.U.L. REv. 1057, 1058 (1955).

2 "The underlying philosophy of the new procedure may be said to consist of two distinctive stands. The first is a shift of emphasis from rigid adherence to a prescribed procedure to a distinct effort to bring about the disposition of every case on its merits without regard to compliance with detailed requirements of adjective law and overlooking any discrepancy or error that does not actually affect the substantive rights of the parties.... Id. at 1059. The second facet of the philosophy ... is ... [an] even greater departure from the ancient moorings. It consists of a modification of the theory of the adversary type of legal procedure, which is part of the warp and woof of AngloSaxon jurisprudence and which distinguishes [it] from continental systems." Id. at 1060.

"What is the fundamental philosophy behind the Federal Rules? In a nutshell, it is that common sense should prevail over the technicalities which grow up under the common law and code system. It aims to direct a fair pattern of procedural steps to be taken but to permit flexibility where the ends of justice will be subserved." Atkinson, Parties and Pleadings in the Missouri Proposed Code of Civil Procedure, 7 Mo. L. REv. 27,28 (1942).

3 i7 Stat. $196(1872)$.

- "[I]n 1938, when the federal rules became effective, they replaced the most confused, irrational, and incomprehensible procedural system that one could imagine. Theoretically, the federal court practice in any particular case on the law side was supposed to follow the procedure in the state where the case was brought. And in equity, the practice was largely prescribed by a short set of rules that had been promulgated . . . in 1912... . The fact that the two classes of civil litigation were processed under totally different procedural systems was bad enough. But particularly in law
} 
It has been said that the "elimination of the 'sporting theory' of justice, the simplification of procedure, and the prompt disposition of controversies on their merits are the great ojectives of the new federal civil practice." To achieve these aims, liberal pretrial discovery devices were incorporated in rules 26 through $36,{ }^{6}$ and sanctions designed to insure compliance with these rules were provided by rule $370^{\circ}$

cases, the idea of conformity to state practice . . . had failed miserably in operation. There is no need ... to recapitulate all of its many well-known defects." Tolman, Discovery under the Federal Rules: Production of Documents and the Work Product of the Lawyer, 58 CoLum. L. REv. 498,499 (1958).

"[In 1938$]$ civil procedure in the federal conrts was ... in a state of chaos. ... $[T]$ here were forty-nine different categories of procedure ... in actions at law, one in each of the states, and one in the District of Columbia. The various kinds of practice ranged from original, simon-pure common-law pleading to code pleading in its different varieties." Holtzoff, Origins and Sources of the Federal Rules of Civil Procedure, 30 N.Y.U.L. REv. 1057 (1955). See also note 2 supra.

"Holtzoff, Instruments of Discovery Under Federal Rules of Civil Procedure, $4 \mathrm{I}$ MICH. L. REV. 205 (1942).

'The array of discovery devices contained in rules 26 through 36 include: liberal and extensive deposition rights (rules 26 through 32); interrogatories to parties (rule 33); discovery and production of documents and things for inspection, copying or photographing (rule 34); physical and mental examinations of persons (rule 35); and the admission of facts and of the genuineness of documents (rule 36 ).

" "Rule 37. Refusal to Make Discovery: Consequences

"(a) Refusal to Answer. If a party or other deponent refuses to answer any question propounded upon oral examination, the examination shall be completed on other matters or adjourned, as the proponent of the question may prefer. Thereafter, on reasonable notice to all persons affected thereby, he may apply to the court in the district where the deposition is taken for an order compelling an answer. Upon the refusal of a deponent to answer any interrogatory subinitted under Rule 31 or upon the refusal of a party to answer any interrogatory submitted under Rnle 33 , the proponent of the question may on like notice make like application for such an order. If the motion is granted and if the court finds that the refusal was without substantial justification the court shall require the refusing party or deponent and the party or attorney advising the refusal or either of them to pay to the examining party the amount of the reasonable expenses incurred in obtaining the order, including reasonable attorney's fees. If the motion is denied and if the court finds that the motion was made without substantial justification, the court shall require the examining party or the attorney advising the motion or both of them to pay to the refusing party or witness the amount of the reasonable expenses incurred in opposing the motion, including reasonable attorney's fees.

"(b) Failure to Comply With Order.

"(I) Contempt. If a party or other witness refuses to be sworn or refuses to answer any question after being directed to do so by the court in the district in which the deposition is being taken, the refusal may be considered a contempt of that court.

"(2) Other Consequences. If any party or an officer or managing agent of a party refuses to obey an order made under subdivision (a) of this rule requiring him.to answer designated qnestions, or an order made under Rule 34 to produce any document or other thing for inspection, copying, or photographing or to permit it to be done; or 
Rule 37 has been left untouched by the successive proposals of the Advisory Committee on Rules for Civil Procedure, although recommendations to amend other rules have frequently been offered. ${ }^{8}$ Yet, the Committee's evident satisfaction with the rule is not shared by all. Professor Rosenberg and others have criticized rule 37 as being in-

to permit entry upon land or other property, or an order made under Rule 35 requiring him to submit to a physical or mental examination, the court may make such orders in regard to the refusal as are just, and among others the following:

"( $i$ ) An order that the matters regarding which the questions were asked, or the character or description of the thing or land, or the contents of the paper, or the physical or mental condition of the party, or any other designated fact shall be taken to be established for the purposes of the action in accordance with the claim of the party obtaining the order;

"(ii) An order refusing to allow the disobedient party to support or oppose designated claims or defenses, or prohibiting him from introducing in evidence designated documents or things or items of testimony, or from introducing evidence of physical or mental condition;

"(iii) An order striking out pleadings or parts thereof, or staying further proceedings until the order is obeyed, or dismissing the action or proceeding or any part thereof, or rendering a judgment by default agaist the disobedient party;

"(iv) In lieu of any of the foregoing orders or in addition thereto, an order directing the arrest of any party or agent of a party for disobeying any of such orders except an order to submit to a physical or mental examination.

"(c) Expenses on Refusal to Admit. If a party, after being served with a request under Rule 36 to admit the genuineness of any documents or the truth of any matters of fact, serves a sworn denial thereof and if the party requesting the admissions thereafter proves the genuineness of any such document or the truth of any such matter of fact, he may apply to the court for an order requiring the other party to pay him the reasonable expenses incurred in making such proof, including reasonable attorney's fees. Unless the court finds that there were good reasons for the denial or that the admissions sought were of no substantial importance, the order shall be made.

"(d) Failure of Party to Attend or Serve Answers. If a party or an officer or managing agent of a party wilfully fails to appear before the officer who is to take his deposition, after being served with a proper notice, or fails to serve answers to interrogatories submitted under Rule 33, after proper service of such interrogatories, the court on motion and notice may strike out all or any part of any pleading of that party, or dismiss the action or proceeding or any part thereof, or enter a judgment by default against that party.

“( (c) Failure to Respond to Letters Rogatory. A subpoena may be issued as provided in Title 28 U.S.C., $\$ 1783$, under the circumstances and conditions therein stated. As amended Dec. 29, 1948, eff. Oct. $20,1949$.

"(f) Expenses Against the Uniled States. Expenses and attorney's fees are not to be imposed upon the United States under this rule."

- Advisory Committee on Rules for Civil Procedure, Report of Proposed Amendments to Rules of Civil Procedure for the United States District CourTs $45-47$ (1955). This report constitutes the most recent recommendations by the Advisory Committee for changes to the Federal Rules of Civil Procedure. No significant changes have been made in rule 37 since its original enactment. 
effective, ambiguous, and of inadequate support to the procedures made available by rules 26 through $36 .^{9}$

One basic difficulty in the administration of rule 37 springs from the simple fact that the rule is not explicitly stated to be the exclusive source of judicial sanctions supporting the discovery rules. There can be little doubt that the authors of the Rules intended it to be so. ${ }^{10}$ With increasing frequency, however, courts have gone outside rule 37 , basing punishments for noncompliance with discovery orders upon rule $4 \mathrm{I}$ (b) or upon so called "inherent powers."11 The unfortunate result has been a wide divergence in sanctions actually applied.

Aside from what rule 37 does not say, grave difficulties are also caused by what it does say. The main caption of the rule, for example, is "Refusal to Make Discovery; Consequences." (Emphasis added.) Yet, its four subdivisions alternate between the words "refusal" and "failure." Since "refusal" connotes intentional noncompliance and "failure" suggests omissive noncompliance, district court judges have been uncertain as to exactly what behavior will properly warrant invocation of the sanctions of rule $37 .{ }^{12}$

Again, the word "wilfully," though it appears but once, ${ }^{13}$ has caused trouble, some judges and commentators contending and others denying ${ }^{14}$

\footnotetext{
- "[T] wenty ycars of use have exposed enough flaws in language, gaps in coverage, and anomalies in application to warrant its revision." Rosenberg, Sanctions to Effectuate Pretrial Discovery, 58 Colum. L. REv. 480, 486 (1958).

10 'Rule 37 was unmistakably designed to generate the principal enforcement power behind the array of discovery procedures and was doubtless intended to be the exclusive source of authority to punish evasion." Id. at 483 .

${ }^{11}$ Other alternative sources of sanctioning power, aside from rule $4 \mathrm{r}(\mathrm{b})$ and "inherent powers," are rule $45(f)$, which concerns itself with subpoenas, and various federal contempt statutes, notably I 8 U.S.C. $\$ 40$ I (1952) (formerly 28 U.S.C. $\$ 385$ (1940)), and I Stat. $73(1789)$, (repealed, 62 Stat. 984 (1948) because it was superseded by the Federal Rules of Civil Procedure).

${ }^{12}$ Brookdale Mill, Inc. v. Rowley, 218 F.2d 728 (6th Cir. 1954); Valenstein v. Bayonne Bolt Corp., 6 F.R.D. 363 (E.D.N.Y. 1946); Dulin v. West, to FeD. Rules SERv. 37d.33, Case 1 (W.D. Mo. Nov. 30, 1946).

${ }^{12}$ FED. R. Civ. p. 37 (d).

16 The federal courts are in total disagreement on the necessity of wilfulness as a prerequisite to the imposition of sanctions under rule 37. A substantial number of cases have been decided without any allusion to the issue of wilfulness. A recent case, Milewski v. Schneider Transportation Co., 238 F.2d 397 (6th Cir. 1956), which involved an action under the Jones Act, was dismissed by the district court because the plaintiff failed to respond to interrogatories. Though the lower court made no reference to wilfulness, the court of appeals affirmed in a per curiam decision, merely noting that "the district judge did not abuse his discretion." Id. at 398 . The following cases have employed a similar approach: Scheser v. American Milk Products Co., Inc,
} 
that "wilfulness" is always a prerequisite to the meting out of sanctions under the rule.

And lurking within the text of rule 37 , there is potentially still another problem: Under what circumstances does a dismissal for noncompliance with discovery rules without full adjudication on the merits comport with the constitutional requirements of due process?

In Societe Internationale Pour Participations Industrielles et Commerciales, S.A. v. Rogers, ${ }^{15}$ the Supreme Court took a giant step toward resolution of some of these problems. This case involved a Swiss holding company which had brought an action under section 9 (a) of the Trading with the Enemy $\mathrm{Act}^{16}$ to recover assets seized by the Custodian of Enemy Property during World War II. The Custodian had found that the more than $\$ 100,000,000$ of assets involved in the Societe Internationale case were actually owned or held for the benefit of the I. G. Farbenindustrie, a then enemy firm.

At an early stage in the proceedings, the Government sought, under rule 34 , an order compelling the production of a large number of papers, documents, and books allegedly in the possession or control of the plaintiff. The motion was granted, and the corporation actually produced a substantial quantity of the requested materials, both in Washington and to government agents in Switzerland. . Full compliance was prevented when the Swiss Attorney General, acting under his country's economic secrecy laws, ${ }^{17}$ constructively confiscated all the plaintiff's records and papers still located at its Swiss offices. The Government thereupon moved for a dismissal under rule 37. The district court referred the matter to a special master, who found that the plaintiff had at all times acted in utmost good faith and had in no way conspired with the Swiss authorities. Although the court accepted the master's findings, a dismissal with prejudice was granted. ${ }^{18}$ The Court of Appeals for the

8 F.R.D. 259 (S.D.N.Y. 1948); Dictograph Products, Inc. v. Kentworth Corp., 7 F.R.D. 543 (W.D. Ky. 1947).

Conversely, cases have held that there can be no imposition of sanctions under rule 37 unless wilfulness is shown: Gill v. Stolow, 240 F.2d 669 (2d Cir. 1957); Ross v. True Temper Corp., $x$ I F.R.D. $3^{\circ} 7$ (N.D. Ohio 1951); Kiachif v. Philco International Corp., to F.R.D. 278 (S.D.N.Y. 1950).

${ }^{15} 357$ U.S. 197 (1958). [Hereinafter cited as Societe Internationale.]

${ }_{40}^{16}$ STAT. 419 (1919), as amended, 50 U.S.C. (App. 1952).

17 Swiss PeNal CODE \& 273; Swiss Bank Law \& 47 .

${ }^{18}$ Societe Internationale v. McGranery, 111 F. Supp. 435 (D.D.C. 1953). The Court of Appeals modified the dismissal to allow an additional 6 months for compliance. Societe Internationale v. Brownell, 225 F.2d 532 (D.C. Cir. 1955). 
District of Columbia Circuit affirmed.19 In a unanimous opinion by Mr. Justice Harlan, the United States Supreme Court reversed the judgment of the lower court and ordered a trial on the merits. ${ }^{20}$

Rule 37 As the Exclusive Source of Sanctioning Power under the Federal Rules

The extent of excursions beyond the confines of rule 37 for sanctioning power is demonstrated by the background of the Societe Internationale case. ${ }^{21}$ When the district court granted the Government's motion for dismissal because of noncompliance with a discovery order issued pursuant to rule 34 , it did so on the basis of undefined inherent equity powers, ${ }^{22}$ although the court acknowledged that rule 37 could have supported its ruling. ${ }^{23}$ The court of appeals, affirming the judgment, noted that the dismissal would more properly have been predicated upon rule $4 \mathrm{I}(\mathrm{b}):{ }^{24}$

Rule 37, apart, Rule 4I(b) would permit dismissal for 'failure' of the plaintiff to comply with an order of the court, thus reflecting the power thought by the Rule framers to reside in the court aside from the specific confines of Rule 37 .

In retrospect, it is difficult to glean from the cases exactly why district court judges have found it necessary to look beyond rule 37 for sanctioning authority. The very text of the rule suggests that it, and it alone, was to constitute the basis for pretrial punishments. This contention is further fortified by the fact the rule directly follows the ten discovery rules in that portion devoted to pretrial procedures. Yet, district court judges not infrequently have utilized inappropriate rules and the plentiful array of federal contempt statutes as alternate sources of sanctioning power. ${ }^{25}$

In any event, it appears that the problem has been resolved by the

${ }^{20}$ Societe Internationale v. Brownell, 243 F.2d 254 (D.C. Cir.), cert. granted, 355 U.S. 812 (1957).

${ }^{20}$ Societe Internationale v. Rogers, 357 U.S. 197 (1958).

21 Ibid.

22 "[A] court has inherent power to disiniss a suit, stay a trial or impose other limitations on the right to proceed with trial when it is established a party plaintiff has failed to comply with order of the court issued pursuant to its rules." Societe Internationale v. McGranery, 111 F. Supp. 435,447 (D.D.C. 1953).

${ }^{23}$ "The order of dismissal appears to be justified under Rule 37 (b) (2) (iii) of the Federal Rules of Civil Procedure." Id. at $4+6$.

${ }^{24}$ Societe Internationale v. Brownell, 225 F.2d 532, 538-39 (D.C. Cir. 1955).

${ }^{25}$ See note I I supra. 
holding of the Societe Internationale case. The Supreme Court, after examining the entire question of the source of sanctioning authority for noncompliance with pretrial discovery orders under the federal rules, stated $:^{28}$

In our opinion, whether a court has power to dismiss a complaint because of non-compliance with a production order depends exclusively upon Rule 37, which addresses itself with particularity to the consequences of a failure to make discovery.... There is no need to resort to Rule $4 \mathrm{r}(\mathrm{b})$, which appears in that part of the Rules concerned with trials and which lacks specific reference to discovery.

The Court also criticized the use of nebulous "inherent powers" as employed by the court of appeals. ${ }^{27}$ This unequivocal stand by the Supreme Court should suffice to curb the inappropriate use of rule $4 \mathrm{I}(\mathrm{b})$ and other alternative sources of sanctioning power.

The Court's words on this central problem in the discovery process will undoubtedly have salutary effect. However, a specific amendment to the rule seems, nevertheless, desirable. In any case, the Court's unqualified position will serve, at least, as an interim guidepost to the district courts until such time as a definitive change to the rule is promulgated.

\section{The "Refusai"__Failure" Dichotomy}

Perhaps one of the more plausible reasons for expeditions beyond the confines of rule 37 is the fact that, without apparent significance, the headings of the four subdivisions of rule 37 alternate between the use of the words "refusal" and "failure." One explanation for this inconsistency is that the framers vaguely desired to indicate that rule 37 was to have application to cases where the disobedient party acted either wilfully or merely negligently. ${ }^{28}$ Still other explanations have been advanced. For example, perhaps the draftsmen of the rule intended what they said, that those subdivisions headed "refusal" should apply

\footnotetext{
${ }^{28} 357$ U.S. 197, 207 (1958).

${ }^{37}$ "Reliance upon ... 'inherent power,' can only obscure analysis of the problem before us." Ibid.

${ }^{28}$ "It might be argued that the framers of rule 37 deliberately intended to make the penalties under subdivision (d) available in any case of omission to obey a court order, whether heedless or conscious, and for that reason used the word 'failure' in the caption." Rosenberg, Sanctions to Effectuate Pretrial Discovery, 58 Colum. L. Rev. 480,490 (1958).
} 
only to affirmative disobedience, while those subdivisions headed "failure" were to be invoked only in cases of omissive noncompliance. This explanation is less than convincing, however, in as much as the main caption of the rule reads simply: "Refusal to Make Discovery: Consequences." (Emphasis added.)

Regardless of the reasons for this semantic incongruity in rule 37, the practical effect has been that some courts have construed the rule as applicable only to "affirmative refusals" and have, therefore, declined to invoke the rule in cases of unintentional noncompliance. ${ }^{28}$ Conversely, other courts have held that rule 37 is applicable only to such latter failures and have, consequently, felt compelled to go elsewhere for sanctioning authority when confronted with deliberate noncompliance. $^{30}$

In the Societe Internationale case, the district court was enmeshed in the uncertainy evoked by the "failure-refusal" dichotomy. ${ }^{31}$ The Supreme Court, displaying concern with the problem, in its order granting certiorari32 expressly invited counsel on both sides to "discuss ... the power of the District Court to dismiss ... petitioner's complaint under Rule $37(b)(2) \ldots$ for failure to obey its [discovery] order $\ldots$ in the absence of evidence and of findings that the petitioner 'refuses

\footnotetext{
${ }^{20}$ An example is Maresco v. Lambert, 2 F.R.D. ${ }_{163}$ (E.D.N.Y. 1941). The defendant moved for a dismissal under rule 37 (d) because the plaintiff's attorney had negligently failed to comply with a discovery order. The court declined to punish the recusant since "the client should not suffer in this instance because of the lawyer's fault." See also Pang-Tsu Mow v. Republic of China, 201 F.2d 195 (D.C. Cir. 1952), cert. denied, 345 U.S. 925 (1953); Collins v. Wayland, 139 F.2d 677 (9th Cir. 1944); Sanib Corp. v. United Fruit Co., 135 F. Supp. 764 (S.D.N.Y. 1955); Spencer v. Hitz Construction Co., 18 FEd. Rules SERv. 37d.31, Case 2 (D. Mont. July 14, 1952).

${ }^{30}$ Duell v. Duell, 7 F.R.D. 334 (D.D.C. 1947 ), reversed, 178 F.2d 683 (D.C. Cir. 1949); Crosley Radio Corp. v. Hieb, 4o F. Supp. 261 (S.D. Iowa 1941).

s2 "The order of dismissal appears to be justifed under Rule $37(\mathrm{~b})(2)$ (iii) of the Federal Rules of Civil Procedure. Rule $37(\mathrm{~b})(\mathrm{l})$ provides that refusal (emphasis added) to be sworn or to answer a question may be considered a contempt of court. Of course, contempt of court involves a wilful act. . Rule 37 (d) ennumerates the sanctions which may be imposed for the wilful failure to appear or to serve answers. Here the word 'wilful' is used. These two rules therefore clearly deal with wilful acts. However, Rule 37 (b) (2) (iii) makes no mention of contempt or wilful refusal. The word 'refusal' is defined as synonymous with 'declination'.... In this case we have noted that the plaintiff with the ... papers in his actual possession has 'refused' or 'declined' to exhibit . . . as ordered by this court. That plaintiff may have had good reason for its refusal would make the act nonetheless a refusal." Societe Internationale v. McGranery, II I F. Supp. 435, 446 (D.D.C. 1953).

${ }^{39} 355$ U.S. 812 (1957).
} 
to obey....'" Apparently, the Court's consideration of this dilemma has produced a solution: ${ }^{33}$

[W] think that a party 'refuses to obey' simply by failing to comply with an order. So construed the Rule allows a court all the flexibility it might need in framing an order appropriate to a particular situation.

It thus appears that the Court considers that the oscillation between "refusal" and "failure" in the text of the rule was designed to enable district courts to apply any part of rule 37 as appropriate to the circumstances of any particular case. So interpreted, the exercise of great discretion is permissible, and the need for going beyond rule 37 is obviated.

\section{The Element of Wilfulness}

Recognizing that the "wilfulness labyrinth" ${ }^{34}$ also required clarification, the Court in the Societe Internationale case undertook to resolve the issue in so far as the facts of that case permitted. ${ }^{35}$ The Court found the district court had erred in dismissing the suit with prejudice, since the petitioner's noncompliance was fostered by an inability not of its own making and "not [due] to wilfulness, bad faith, or any fault of the petitioner."36 (Emphasis added.) The quoted language seems to indicate that a court may not dismiss an action with prejudice under rule 37 unless wilfulness is affirmatively shown. An earlier portion of the opinion, however, suggests that the Court would not necessarily disapprove a sanction based solely on involuntary noncompliance, but that

357 U.S. 197, 208 (1958).

${ }^{34}$ See note 14 supra.

${ }^{35}$ This issue of wilfulness is intertwined with the concept of what constitutes "control" within the purview of rule 34. As a result, were the court to take a liberal view of what is control, the policies of the Trading with the Enemy Act would not be subserved because an enemy alien would find it easier to form fictitious corporations or to employ similar devices to evade the consequences of the Act.

"The propriety of the use to which [rule 34] is put depends upon the circumstances of a given case, and we hold only that accommodation of the Rule in this instance to the policies underlying the Trading with the Enemy Act justifed the action of the District Court in issuing the production order." Societe Internationale v. Rogers, 357 U.S. 197,206 (1958).

The policy of the Trading with the Enerny Act was stated by the Court in the leading case of Clark v. Uebersee Finanz-Korporation, A.G., 332 U.S. 480, 985 (1947): "[T]o reach enemy interests which masqueraded under . . . innocent fronts."

${ }^{30}$ Societe Internationale v. Rogers, 357 U.S. 197, 212 (1958). 
the punishment dispensed should be commensurate with the quality of the recusant's conduct. ${ }^{37}$

The peculiar facts of the Societe Internationale case preclude any assumption that the decision has totally resolved the wilfulness controversy. ${ }^{38}$ It must be borne in mind that the petitioner did make extensive efforts to comply with the pretrial discovery order and that it was the interdiction of the laws of a friendly foreign power which prevented complete compliance..$^{30}$ The fact that the legislation of a foreign nation was involved may have influenced the Court, since a lack of solicitude for the laws of another country might adversely affect our international relations.

\section{Constitutional Pitfalls}

The Court in the Societe Internationale case noted, but neatly avoided, certain constitutional questions which arise when a case is dismissed with prejudice before a full trial on the merits because of noncompliance with a pretrial discovery order. ${ }^{40}$ The problem becomes especially acute where, as in the instant case, the recusant made extensive good faith efforts to comply.

The constitutional basis of procedural rules authorizing dismissals for noncompliance with pretrial orders before a trial on the merits was first authoritatively stated in the case of Hovey $v$. Elliot. ${ }^{41}$ There, the

${ }^{37}$ "Whatever its reasons, petitioner did not comply with the production order. Such reasons, and the wilfulness or good faith of the petitioner, can hardly affect the fact of non-compliance and are relevant only to the path which the district court might follow in dealing with the petitioner's failure to comply." Id. at 208.

${ }^{88}$ See note 35 supra.

${ }^{30}$ The Court cautioned that the situation in the Societe Internationale case is to be distinguished from non-compliance which is engendered by fear that disclosure might expose the recusant to prosecution under the laws of another nation. In the instant case, compliance itself was a criminal act under Swiss law.

The Court said: "It is hardly debatable that fear of criminal prosecution constitutes a weighty excuse for nonproduction, and this excuse is not weakened because the laws preventing compliance are those of a foreign sovereign. Of course this situation should be distinguished from one where a party claims that compliance with a court's order will reveal facts which may provide basis for criminal prosecution of that party under the penal laws of a foreign sovereign thereby shown to have been violated. . . . Here the findings below establish that the very fact of compliance by disclosure of . . . records will itself constitute the initial violation. . ." Societe Internationale v. Rogers, 357 U.S. 197, 2 I I (1958).

"The provisions of Rule 37 which are here involved must be read in light of the provisions of the Fifth Amendment that no person shall be deprived of property without due process of law...." Id. at 209 .

${ }^{11}{ }_{167}$ U.S. 409 (1897). The Court was most emphatic in its view: "[A] more 
Supreme Court held that dismissal solely for punishment was repugnant to the due process clause of the Constitution. ${ }^{42}$ This holding, rendered in 1897, was modified in 1909 in the case of Hammond Packing Co. v. Arkansas, ${ }^{43}$ where the Court held that sanctions for noncompliance with pretrial discovery orders were not unconstitutional because: : $^{4}$

[In this case] the preservation of due process was secured by the presumption that the refusal to produce evidence material to the administration of due process was but an admission of want of merit in the asserted defense.

It would thus appear that denying a trial merely because of disobedience to a pretrial discovery order, despite a good faith effort toward compliance by the recusant, is a denial of due process. ${ }^{45}$ The holding in Hovey v. Elliot definitely establishes that dismissal as punishment per se is unconstitutional. Constitutionality, therefore, must necessarily depend on the "presumption" rationale of the Hammond Packing Co. case. Yet, it does not seem logical to presume that a party has no faith in his defense if he diligently attempts to comply with the court's order but is frustrated in his endeavor by force beyond his control. ${ }^{48}$

fundamental question yet remains ... whether a court possessing plenary power to punish for contempt ... unlimited by statute, has the right to ... refuse to allow the party summoned to answer or strike his answer . . . suppress the testimony in his favor, and condemn him without consideration thereof and without a hearing, on the theory that he has been guilty of . . . contempt. . . . The mere statement of this proposition would seem, in reason and conscience, to render imperative a negative answer. The fundamental conception of a court of justice is condemnation only after hearing." Id. at 413-14.

10 "[W]e rest our decision on the want of power in the courts of the District of Columbia to suppress an answer of parties defendant, and after so doing to render a decree pro confesso as in case of default for want of an answer. ..." Id. at 447 .

13212 U.S. 322 (1909). 14 Id. at 351.

${ }^{15}$ The framers of the Federal Rules of Civil Procedure were keenly aware of the constitutional difficulties which might present themselves in the field of pretrial discovery sanctions. In their notes to the draft of rule 37, the Advisory Committee said:

"The provisions of this rule authorizing orders establishing facts or excluding evidence or striking pleadings, or authorizing judgments of dismissal or default, for refusal to answer questions or permit inspection or otherwise make discovery, are in accord with Hammond Packing Co. 0 . Arkansas, 212 U.S. 322 (1909), which distinguishes between the justifiable use of such measures as a means of compelling the production of evidence, and their unjustifiable use, as in Hovey v. Elliott, i67 U.S. 409 (1897), for the mere purpose of punishing for contempt." ADVISORY COMMITTEE on Rules for Civil Procedure, Notes to the Rules of Civil Procedure for the District Courts of the United States 33 (1938), quoted in 4 Moorf, Fenfral Practice § 37.01, 2803-04 (2d ed. 1950).

"These two decisions leave open the question whether Fifth Amendment due 
The facts of the Societe Internationale case well illustrate the constitutional danger which lurks within rule 37: The plaintiff was ordered to produce papers under the terms of rule 34. He made extensive efforts to comply and had actually produced a substantial amount of the requested material. Yet, the court granted the Government's motion for a dismissal with prejudice under rule 37 , despite positive findings by a court appointed master that the plaintiff had at all times acted with unquestioned good faith. ${ }^{47}$

The constitutional issue is best viewed against the background of its own history. In the Hovey case a decree pro confesso was entered after striking the defendant's answer, as punishment for his refusal to obey a court order for production of papers. Significantly, the ratio decidendi indicated that in the past, courts had considered the practice of curt dismissals for pretrial disobedience permissible under our Constitution, since it was thought to have been sanctioned by the common law courts, particularly in Chancery. ${ }^{48}$ Mr. Justice White, speaking for the Court,

process is violated by the striking of a complaint because of a plaintiff's inability, despite good faith efforts, to coinply with a pretrial production order. The presumption utilized by the Court in the Hammond case might well falter under such circunstances. . . Certainly substantial constitutional questions are provoked by such action." Societe Internationale v. Rogers, 357 U.S. 197, 210 (1958).

The problem of the constitutionality of certain presumptions such as that used by the Court in the Hammond Packing Co. case is an old one. The most difficult problems regarding presumptions, however, are presented in the field of legislation. Perhaps the leading case on the subject is Tot v. United States, 319 U.S. 463 (1943), wherein it was held that a statutory presumption does not coinport with the requireinents of due process unless there is a "rational connection" between the facts proved and the ultimate fact presumed. There seems to be no compelling reason why judicially created presumptions should not be similarly viewed. The ramifications of the Tot case are ably discussed in Note, 56 HARv. L. REv. 1324 (1943). See also: Morrison v. California, 291 U.S. 82 (1934); Manley v. Georgia, 279 U.S. I (1929); Bailey v. Alabama, 2 I9 U.S. 2 I9 (19II); 4 WIGMORE, EVIDENCE $\$ \$ 1353-56$ (3d ed. 1940).

${ }^{\star 7}$ Societe Internationale v. McGranery, 11 I F. Supp. 435 (D.D.C. I955).

18 "We are brought to the conclusion that there has long been exerted by the Court of Chancery in England the power to refuse to hear the defendant when he was in contempt of the court by disobeying its orders, and that that power was in the Courts of Chancery of this country." Walker v. Walker, 82 N.Y. 260, 264 (1880).

"[A]ccording to an unbroken chain of authorities, reaching back to the earliest times, such power [to punish for contempt], although arbitrary in its nature and liable to abuse, is absolutely essential to the protection of the courts in the discharge of their functions." Ex parte Terry, 128 U.S. 289,313 (1888).

"It seems to have been the ancient common law rule that where a party was charged with a constructive contempt of court-that is, with doing some act in disobedience of the court's order not in the presence of the court-he could answer under oath; and if by his answer he purged himself of the contempt, he was discharged." Carson v. Ennis, 146 Ga. 726, 728-29, 92 S.E. 221,222 (1917). 
demonstrated by a rich and thorough examination of every authcritative source of the common law that the practice of dismissal with prejudice for punishment ${ }^{49}$

... is based upon a too strict and literal rendering of general language to be found in isolated passages contained in the works of writers on ancient law ... and on loose statements as to the practice of the Court of Chancery. ...

Thus, it can be perceived that the entire concept of dismissal with prejudice for noncompliance with pretrial discovery ordèrs, at least to the extent that it has been accepted, is actually based on a weak constitutional rationalization conceived on a misinterpretation of certain anachronistic common law practices. ${ }^{50}$ Nonetheless, the constitutional propriety of pretrial sanctions was somewhat fortified by the nuances of Hammond Packing Co.

From the situations presented in cases such as Societe Internationale, it is to be gathered that an undeniable constitutional problem exists and should be resolved. Since the Supreme Court cannot eliminate the problem by judicial pronouncement unless the question is presented in a case or controversy, it would appear that the most desirable approach lies in outright amendment to rule 37. Any proposed amendment should stipulate unequivocally that an involuntary dismissal with prejudice cannot be invoked unless the recusant is in wilful bad faith and has, by his conduct, demonstrated a discernible lack of confidence in the merits of his case.

By so amending the rule, another complementary problem would be simultaneously resolved. Since the rule, in its present form, is ambiguous upon the necessity, for wilfulness under rule 37 , a positive expression to the effect that bad faith and wilfulness are necessary from a constitutional standpoint would eliminate any doubt concerning the quality of conduct required before the power of rule 37 can be invoked.

${ }^{10}$ Hovey v. Elliott, 167 U.S. 409, 419 (1897).

50 "The demonstration of the unsoundness of the contention that courts of equity have claimed and excrcised the power to suppress an answer and thereupon render a decree pro confesso, which results from the foregoing review of the authorities, is strengthened by the reflection that if such power obtained, then the ancient common law doctrine of 'outlawry,' and that of the continental systems as to 'civil death,' would be a part of the chancery law, a theory which could not be admitted without violating the rudimentary conceptions of the fundamental rights of the citizen." Id. at 444 . 


\section{CoNCLUSION}

Although the Societe Internationale case will be viewed as a substantial advance in the field of discovery, the flaws in rule 37 are not completely rectified. Amendment and modification are still very much in order. Moreover, it must be recognized that the formal wording of rule 37 does not present the most insuperable obstacle to its effective administration. Should the text of the rule be amended and reinterpreted so as to attain the ultimate in clarity and understanding, the task still would be by no means complete. A set of rules-particularly procedural rules-is no better, no more effective than the quality of its application. Uniform and realistic judicial enforcement, then, is the final, but controlling, goal to be pursued.

It is undeniable that the framers of the Rules contemplated that rule 37 should be an instrument of drastic action against those who would thwart the discovery process. The tendency, however, has been to withhold serious sanctions in return for promises by the recusant to comply at some future time. The reluctance to mete out the full measure of punishment that the circumstances might require is, in the main, attributable to hesitancy to harm an innocent litigant who might be victimized by the errors of his attorney, or to the hope that the suit might eventually be. resolved on the merits, conditioned upon future compliance.

What is the net result of this diluted judicial application? The principal result is that rule 37 has been relegated too often to the station of "merely another procedural technicality" to be lived with or tolerated, rather than respected and observed. On the other hand, the overzealous judge who terrorizes a party by an unnecessarily severe policy concerning the discovery process is as aberrational as is the lenient judge who ever seeks to cajole a party into compliance by continually allowing another chance.

Recognizing that discovery can be, and has been, used as a means of harassing the opposite side, and that discovery can cause unnecessary hardship to an innocent client, the federal courts must chart a middle course which insures compliance and uniformity; which permits firmness, yet justice. 